\title{
PENGARUH MODEL PEMBELAJARAN BERBASIS MASALAH TERHADAP HASIL BELAJAR SISWA
}

\author{
Reky B Naibaho *) dan Rahmatsyah **) \\ (Prodi Pendidikan Fisika FMIPA Unimed) \\ rekynaibaho@yahoo.co.id \\ *) Mahasiswa Pendidikan Fisika Unimed \\ **) Dosen Fisika Unimed
}

\begin{abstract}
ABSTRAK
Penelitian ini bertujuan untuk mengetahui pengaruh model pembelajaran berbasis masalah terhadap hasil belajar siswa pada materi pokok suhu dan kalor. Jenis penelitian ini adalah quasi experiment dengan two group pre-test-post-test design. Populasi adalah seluruh siswa kelas X SMA Santo Mikhael Pangururan terdiri dari 6 kelas. Sampel penelitian diambil 2 kelas yang ditentukan dengan cluster random sampling, yaitu kelas X-D sebagai kelas eksperimen dengan model pembelajaran berbasis masalah dan kelas X-A sebagai kelas kontrol dengan pembelajaran konvensional. Instrumen yang digunakan adalah tes hasil belajar dalam bentuk pilihan berganda sebanyak 20 soal yang telah divalidasi dan lembar observasi aktivitas belajar siswa. Untuk menguji hipotesis digunakan uji beda (uji t), setelah uji prasyarat dilakukan, yaitu uji normalitas dan uji homogenitas. Hasil penelitian menunjukkan: (1) model pembelajaran berbasis masalah dapat meningkatkan aktivitas belajar siswa dan (2) ada pengaruh model pembelajaran berbasis masalah terhadap hasil belajar siswa pada materi pokok suhu dan kalor.
\end{abstract}

Kata kunci: Model pembelajaran berbasis masalah, hasil belajar, aktivitas.

\section{ABSTRACT}

This research aimed to know the effect of problem based learning model on students' learning outcomes in the subject matter temperature and heat. The type of research was quasi-experimental with two group pre-testpost-test design. The population were the tenth grade students of SMA Santo Mikhael Pangururan consisting of 6 classes. Samples were taken 2 classes determined by cluster random sampling technique, the class $X-D$ as experiment class with the use of problem based learning model and class $X$ $A$ as control class using convensional learning. The instruments used were test of learning outcomes in the form of multiple choice as much as 20 questions that have been validated and the observation sheet students' learning activities. To examine the hypothesis was used different test ( $t$ test), after the prerequisite test is done, the test of normality and homogeneity test. The results showed that: (1) the problem based learning model can improve students' activities and (2) the influence of problem based learning model to student learning outcomes in the subject matter temperature and heat.

Keywords: Problem based learning model, learning outcome, activity. 
PENDAHULUAN

Pendidikan merupakan

proses mendidik, yaitu suatu

proses dalam rangka

mempengaruhi peserta didik agar

mampu menyesuaikan diri sebaik mungkin dengan lingkungannya, sehingga akan menimbulkan perubahan dalam dirinya. Pendidikan harus membantu perkembangan terciptanya individu yang kritis dengan tingkat kreativitas yang sangat tinggi dan tingkat keterampilan berpikir yang lebih tinggi pula (Rusman, 2012:230).

Hal yang biasa terjadi pada proses pembelajaran, siswa hanya berperan sebagai penerima materi pelajaran. Padahal seharusnya siswa turut serta aktif dalam proses pembelajaran sehingga mampu meningkatkan hasil belajar mengenai pokok bahasan yang sedang dipelajari melalui masalah. Menurut Tan (2004:7), ketika peserta didik mempelajari sesuatu dan diberikan masalah, hal tersebut memberikan siswa tantangan untuk berfikir lebih dalam.

Berdasarkan uraian yang telah disampaikan di atas, ditemukan masalah rendahnya hasil belajar siswa disebabkan proses pembelajaran yang tidak berorientasi pada masalah. Diperlukan model pembelajaran berbasis masalah memfasilitasi siswa untuk menjadi pebelajar secara aktif dalam menyelesaikan masalah, hal ini diungkapkan oleh Barbara dan Younghoon (Tan, 2004: 168). Albanese dan Mitchel (Tan, 2004:7) memperkuat bahwa model pembelajaran berbasis masalah lebih baik dibandingkan dengan model pembelajaran konvensional, karena mampu mengkonstruksi konsep dan mengembangkan keterampilan proses. Sebagai solusi atas permasalahan di atas, digunakan model pembelajaran berbasis masalah sebagai suatu model pembelajaran yang menggunakan masalah sebagai titik tolak pembelajaran.

Pembelajaran berbasis masalah adalah salah satu variasai dalam meningkatkan interaksi dalam proses pembelajaran, sehingga proses pembelajaran tidak hanya berpusat dari guru. Esensi model pembelajaran berbasis masalah berupa menyuguhkan berbagai situasi bermasalah yang autentik dan bermakna kepada siswa, yang dapat berfungsi sebagai batu loncatan untuk investigasi dan penyelidikan (Arends, 2008:41; Rusman, 2012:229; Pulungan, 2012:39; Saputri, dkk., 2013). Melalui model pembelajaran berbasis masalah siswa dapat menyusun pengetahuannya sendiri, meningkatkan keterampilan berpikir kritis, dan meningkatkan kepercayaan dirinya (Sanjaya, 2011:220).

Menurut Amir (2010:27), manfaat model pembelajaran berbasis masalah bagi pemelajar adalah meningkatkan fokus pada pengetahuan yang relevan; menjadi lebih ingat dan meningkatkan pemahaman pemelajar atas materi ajar; mendorong untuk berpikir; membangun kecakapan belajar; 
membangun kerja tim, kepemimpinan, keterampilan social dan memotivasi pebelajar.

Tujuan penelitian adalah untuk mengetahui perbedaan hasil belajar siswa akibat pengaruh model pembelajaran berbasis masalah materi pokok suhu dan kalor di kelas X SMA Santo Mikhael Pangururan T.P. 2014/2015 dan mengetahui aktivitas belajar siswa selama proses belajar mengajar dengan menggunakan model pembelajaran berbasis masalah.

\section{METODE PENELITIAN}

Jenis penelitian ini adalah quasi experiment dengan two group pre-test-posttest design. Populasinya seluruh siswa kelas $\mathrm{X}$, yang terdiri dari 6 kelas. Teknik pengambilan sampel dilakukan dengan cara teknik sampel kelas acak (cluster random sampling). Sampel kelas diambil dari populasi sebanyak 2 kelas, yaitu kelas X-D dengan menggunakan model pembelajaran berbasis masalah dan kelas X-A dengan menggunakan pembelajaran konvensional.

Alat pengumpul data dalam penelitian ini adalah tes hasil belajar berbentuk pilihan berganda dengan jumlah 20 soal yang sudah divalidasikan dan observasi. Tes hasil belajar ini digunakan untuk mengetahui kemampuan siswa pada tingkat kognitif dan observasi untuk mengetahui aktivitas belajar siswa.

Uji hipotesis digunakan dengan membandingkan rata-rata skor hasil belajar yang dicapai baik kelompok eksperimen maupun kelompok kontrol. Data yang diperoleh ditabulasikan kemudian dicari rata-ratanya. Sebelum dilakukan penganalisisan data, terlebih dahulu ditentukan skor masing-masing kelompok sampel lalu dilakukan pengolahan data dengan langkah-langkah sebagai berikut:

a) Menghitung nilai rata-rata dan simpangan baku

b) Uji normalitas dengan menggunakan uji lilliefors

c) Uji homogenitas dengan menggunakan uji kesamaan dua varians

Uji normalitas dan uji homogenitas dimaksudkan sebagai prasyarat melakukan uji hipotesis jika populasi terdistribusi normal dan homogen.

d) Pengujian hipotesis dengan menggunakan uji $\mathrm{t}$

Uji hipotesis dua pihak digunakan untuk mengetahui perbedaan kemampuan awal siswa pada kedua kelompok sampel dan uji hipotesis satu pihak digunakan untuk mengetahui perbedaan hasil belajar siswa pada kedua kelompok saampel.

\section{HASIL DAN PEMBAHASAN}

Adapun hasil penelitian ini adalah bahwa nilai rata-rata pretest kelas eksperimen sebesar 29,00 dan nilai rata-rata pre-test kelas kontrol sebesar 28,75, dimana kemampuan awal kedua kelas dilihat dari hasil pre-test seperti yang ditunjukkan pada Tabel 1. 
Tabel 1. Data Nilai Pre-test Kelas Eksperimen dan Kelas Kontrol

\begin{tabular}{|c|c|c|c|c|c|c|c|}
\hline \multicolumn{4}{|c|}{ Kelas Eksperimen } & \multicolumn{4}{|c|}{ Kelas Kontrol } \\
\hline No & Nilai & Frekuensi & Rata-rata & No & Nilai & Frekuensi & Rata-rata \\
\hline 1 & 15 & 2 & 29,00 & 1 & 15 & 2 & 28,75 \\
\hline 2 & 20 & 8 & & 2 & 20 & 7 & \\
\hline 3 & 25 & 7 & & 3 & 25 & 8 & \\
\hline 4 & 30 & 9 & & 4 & 30 & 10 & \\
\hline 5 & 35 & 9 & & 5 & 35 & 8 & \\
\hline 6 & 40 & 3 & & 6 & 40 & 5 & \\
\hline 7 & 45 & 2 & & & $\sum$ & 40 & \\
\hline & $\Sigma$ & 40 & & & & & \\
\hline
\end{tabular}

Hasil uji normalitas data pre-test pada kedua kelas masingmasing diperoleh $\mathrm{L}_{\text {hitung }}=0,1270$ $<\mathrm{L}_{\text {tabel }}=0,1400$ dan L hitung $^{=}$ $0,1235<\mathrm{L}_{\text {tabel }}=0,1400$. Hasil uji homogenitas pada data pre-test diperoleh $F_{\text {hitung }}=1,187<\mathrm{F}_{\text {tabel }}=$ 1,709. Berdasarkan hasil kedua pengujian ini disimpulkan bahwa populasi berdistribusi normal dan homogen sehingga layak dilakukan uji hipotesis dua pihak dengan hasil uji hipotesis $t_{\text {hitung }}=$ $0,149<\mathrm{t}_{\text {tabel }}=1,994$, maka $\mathrm{H}_{0}$ diterima atau tidak ada perbedaan kemampuan siswa pada kedua kelompok sampel.

Observasi bertujuan untuk mengamati aktivitas belajar siswa selama pembelajaran dengan model pembelajaran berbasis masalah menggunakan animasi. Observasi dilakukan selama kegiatan belajar mengajar yang dilakukan selama tiga kali pertemuan. Aktivitas siswa di kelas eksperimen mengalami peningkatan di stiap pertemuan seperti yang ditunjukkan pada Gambar 1.

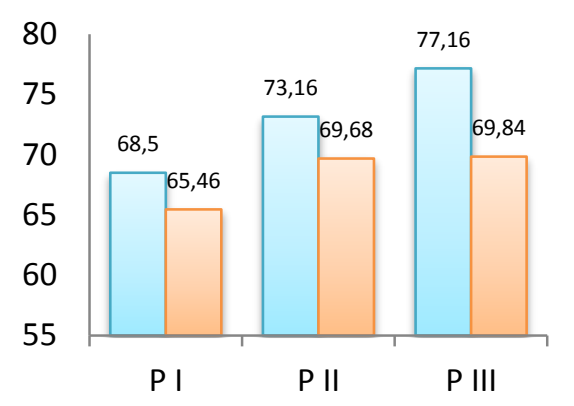

$\square$ Kelas Eksperimen $\square$ Kelas Kontrol

Gambar 1. Diagram batang data aktivitas kelas eksperimen setiap pertemuan

Berdasarkan gambar 1, pertemuan I (P I) diperoleh ratarata aktivitas siswa kelas eksperimen 68,50 dan kelas kontrol 65,48; pada pertemuan II (P II) diperoleh rata-rata aktivitas siswa kelas eksperimen 73,16 dan kelas kontrol 69,68; dan pada pertemuan III (P III) diperoleh rata-rata aktivitas siswa kelas eksperimen 77,16 dan kelas kontrol 69,84; peningkatan aktivitas belajar siswa kelas eksperimen dari pertemuan I sampai pertemuan III dengan ratarata nilai seluruhnya adalah 72,94 
dengan kriteria penilaian aktif. Berdasarkan gambar 2, hasil belajar siswa pada tingkat kemampuan C4, C5 dan C6 menurut taksonomi Bloom, siswa di kelas eksperimen lebih banyak menjawab benar dibandingkan siswa kelas kontrol, hal ini disebabkan karena soal-soal pada tingkat kemampuan ini melibatkan praktek dan pengamatan langsung. Tingkat kemampuan $\mathrm{C} 1, \mathrm{C} 2$ dan $\mathrm{C} 3$ siswa kelas eksperimen dan kelas kontrol hampir sama karena soalsoal lebih mudah dan masih bersifat teoritis.

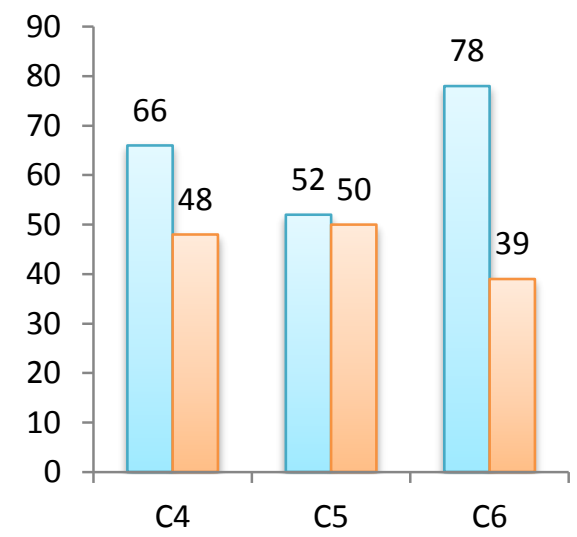

$$
\square \text { Kelas Eksperimen } \square \text { Kelas Kontrol }
$$

\section{Gambar 2. Grafik hasil belajar siswa menurut taksonomi Bloom}

Pernyataan di atas sesuai dengan pendapat Barbara (2001; 49), mengatakan pertanyaan pertanyaan yang bersifat masalah harus menantang siswa untuk mengembangkan keterampilan berpikir ingkat tinggi, sesuai dengan Bloom mereka lebih dahulu melampaui tingkat kognitif yang lebih rendah Bloom yaitu pengetahuan dan pemahaman baru melangkah ke tingkat yang lebih tinggi Bloom, dimana mereka menganalisis, mensintesis dan mengevaluasi.

Berdasarkan tabel 2 data nilai post-test menunjukkan adanya perbedaan hasil belajar kelas eksperimen dengan kelas kontrol yaitu kelas eksperimen memiliki nilai rata-rata pre-test 29,00 dan post-test 57,50, sedangkan pada kelas kontrol memiliki nilai rata-rata pre-test 28,75 dan post-test 47.50. Berdasarkan hasil ini tampak bahwa nilai post-test kelas eksperimen lebih tinggi dibandingkan dengan kelas kontrol. Hasil penelitian menunjukkan bahwa ada pengaruh model pembelajaran berbasis masalah terhadap hasil belajar siswa pada materi pokok suhu dan kalor di kelas X SMA Santo Mikhael Pangururan.

Hasil uji normalitas data post-test pada kedua kelas masing-masing diperoleh $\mathrm{L}_{\text {hitung }}=$ $0,1234<\mathrm{L}_{\text {tabel }}=0,1400$ dan $\mathrm{L}_{\text {hitung }}$ $=0,1299<\mathrm{L}_{\text {tabel }}=0,1400$. Hasil uji homogenitas pada data posttest diperoleh $\mathrm{F}_{\text {hitung }}=1,197<$ $\mathrm{F}_{\text {tabel }}=1,709$. Berdasarkan hasil kedua pengujian ini disimpulkan bahwa populasi berdistribusi normal dan homogen sehingga layak dilakukan uji hipotesis satu pihak dengan hasil uji hipotesis $\mathrm{t}_{\text {hitung }}=4,322>\mathrm{t}_{\text {tabel }}=1,667$, maka $\mathrm{H}_{\mathrm{a}}$ diterima dengan kata lain ada perbedaan hasil belajar siswa pada kelas eksperimen dan kelas kontrol. 
Tabel 2. Data Nilai Post-test Kelas Eksperimen dan Kelas Kontrol

\begin{tabular}{lccccccc}
\hline & \multicolumn{3}{c}{ Kelas Eksperimen } & \multicolumn{4}{c}{ Kelas Kontrol } \\
\hline No & Nilai & Frekuensi & $\begin{array}{c}\text { Rata- } \\
\text { rata }\end{array}$ & No & Nilai & Frekuensi & $\begin{array}{c}\text { Rata- } \\
\text { rata }\end{array}$ \\
\hline $\mathbf{1}$ & 40 & 4 & 57,50 & 1 & 30 & 3 & 47,50 \\
$\mathbf{2}$ & 45 & 1 & & 2 & 35 & 4 & \\
$\mathbf{3}$ & 50 & 9 & & 3 & 40 & 8 & \\
$\mathbf{4}$ & 55 & 6 & 4 & 45 & 6 & \\
$\mathbf{5}$ & 60 & 7 & 5 & 50 & 6 & \\
$\mathbf{6}$ & 65 & 5 & 6 & 55 & 6 & \\
$\mathbf{7}$ & 70 & 6 & 7 & 60 & 4 & \\
$\mathbf{8}$ & 75 & 2 & 8 & 70 & 3 & \\
& $\sum$ & 40 & & \multicolumn{5}{c}{$\sum$} & 40 & \\
\hline
\end{tabular}

Hasil belajar fisika siswa kelas eksperimen lebih baik daripada kelas kontrol karena model pembelajaran berbasis masalah lebih berpusat pada siswa sehingga siswa lebih aktif untuk mengkonstruksi langsung pengetahuan melalui setiap kegiatan yang telah dirancang pada fase model pembelajaran berbasis masalah. Selain itu, dengan adanya pembentukan kelompok pada model pembelajaran berbasis masalah ini membuat terjadinya interaksi antara siswa dengan siswa dan siswa dengan guru, siswa dapat menukar ide satu sama lain, siswa terlatih untuk berpikir kritis dan terampil untuk memecahkan masalah dalam bidang studi fisika.

Hal ini sejalan dengan pernyataan Rusman (2012:230) dalam bukunya bahwa kemampuan berpikir siswa pada pembelajaran berbasis masalah betul-betul dioptimalisasikan melalui proses kerja kelompok atau tim yang sistematis, sehingga siswa dapat memberdayakan, mengasah, menguji, dan mengembangkan kemampuan berpikirnya secara berkesinambungan. Dalam model pembelajaran berbasis masalah sebuah masalah yang dikemukakan kepada siswa harus dapat membangkitkan pemahaman siswa terhadap masalah, sebuah kesadaran akan adanya kesenjangan, pengetahuan, keinginan memecahkan masalah, dan adanya persepsi bahwa mereka mampu memecahkan masalah tersebut.

Peneliti sebelumnya,

Setiawan, dkk., (2012:9), menyimpulkan bahwa terdapat perbedaan hasil belajar siswa yang signifikan dengan menggunakan model pembelajaran berbasis masalah dan pembelajaran konvensional dengan rata-rata nilai post-test kelas eksperimen sebesar 73,77 dan kelas kontrol sebesar 62,76. Suhanda, dkk., (2014:10) juga menyimpulkan bahwa hasil belajar fisika siswa dengan menggunakan model 
pembelajaran berbasis masalah lebih baik dari hasil belajar fisika siswa dengan menggunakan model pembelajaran konvensional dengan rata-rata tes hasil belajar kelas eksperimen adalah 75,13 sedangkan kelas kontrol 66,19. Dilanjutkan Astika, dkk., (2013:9) dengan hasil penelitian menyimpulkan bahwa sikap ilmiah dan keterampilan berpikir kritis siswa yang belajar menggunakan model pembelajaran berbasis masalah lebih baik daripada siswa yang belajar menggunakan model pembelajaran ekspositori.

Kendala yang dihadapi peneliti pada tahap persiapan yaitu membuat instrumen penelitian, peneliti mengalami kesulitan menyajikan soal dan lember kerja siswa (LKS) yang berbasis masalah supaya sesuai dengan model pembelajaran yang dilaksanakan. Fase pertama pada model pembelajaran berbasis masalah adalah menyampaikan orientasi masalah kepada siswa. Masalah yang diberikan harus sesuai dengan apa yang pernah mereka alami. Jadi peneliti harus mampu mengorganisasikan pengalaman siswa dengan masalah yang diberikan atau dengan menampilkan video ataupun animasi yang berisi suatu permasalahan untuk menarik perhatian siswa. Hasil penilaian aktivitas belum dapat memberikan gambaran meningkatkan hasil belajar seperti yang diharapkan, dalam hal ini kelemahan yang terjadi dapat disebabkan oleh penjelasan peneliti yang kurang memadai kepada observer dan banyaknya siswa dalam setiap kelompok yang harus diamati observer. Kesulitan yang dihadapi peneliti yaitu kurang terbiasanya siswa melakukan penyelidikan individu dan kelompok sehingga peneliti memerlukan banyak waktu dalam membimbing pelaksanaan penyelidikan.

Berdasarkan kendala tersebut kepada peneliti selanjutnya sebagai tindak lanjut dari penelitian ini disarankan pada tahap persiapan, instrumen soal dan LKS harus betul-betul disesuaikan dengan model pembelajaran berbasis masalah dan harus divalidasi oleh validator yang benar-benar kompeten dalam bidang pendidikan dan memahami model pembelajaran berbasis masalah. Tahap orientasi siswa pada masalah dilakukan dengan bantuan video atau rekaman fenomena atau peristiwa nyata yang dapat memunculkan masalah dan dapat menarik minat dan motivasi siswa untuk terlibat dalam pemecahan masalah. Implementasi tahapan model pembelajaran berdasarkan masalah lebih disesuaikan supaya setiap deskriptor aktivitas dapat tercapai dengan baik. Peneliti selanjutnya harus benar-benar mempersiapkan perangkat yang akan digunakan, dapat mengkondusifkan kelas pada saat pembelajaran berlangsung dengan cara lebih tegas dalam mengarahkan siswa serta karena jumlah siswa dan aktivitas yang akan diobservasi banyak maka supaya efektif sebaiknya diperlukan satu observer setiap kelompok belajar. 
KESIMPULAN DAN SARAN

Berdasarkan hasil

penelitian, hasil belajar siswa

kelas eksperimen dengan model pembelajaran berbasis masalah lebih baik dibandingkan kelas kontrol. Nilai rata-rata hasil belajar siswa kelas eksperimen adalah 57,50 sedangkan nilai rata-rata hasil belajar siswa kelas kontrol adalah 47,50. Hasil observasi aktivitas belajar siswa kelas eksperimen dengan menggunakan model berbasis masalah adalah 72,94 dengan kriteria penilaian aktif dan kelas kontrol dengan pembelajaran konvensional adalah 68,32 dengan kriteria cukup aktif. Hasil perhitungan uji t diperoleh bahwa bahwa ada perbedaan akibat pengaruh model pembelajaran berbasis masalah terhadap hasil belajar siswa pada materi pokok suhu dan kalor di kelas X SMA Santo Mikhael Pangururan.

Saran untuk peneliti selanjutnya diharapkan pada tahap orientasi siswa pada masalah dapat dilakukan dengan bantuan video atau rekaman fenomena atau peristiwa nyata yang dapat memunculkan masalah dan dapat menarik minat dan motivasi siswa untuk terlibat dalam pemecahan masalah. Implementasi tahapan model pembelajaran berdasarkan masalah lebih disesuaikan supaya setiap deskriptor aktivitas dapat tercapai dengan baik. Menggunakan miodel pembelajaran berbasis masalah dalam proses pembelajaran ataupun penelitian, instrumen seperti soal dan LKS harus sesuai dengan karakteristik model pembelajaran berbasis masalah. Instrumen soal dan LKS harus berbentuk masalah yang aktual, faktual dan konseptual yang sudah divalidasi oleh pakar pada bidang pendidikan.

\section{DAFTAR PUSTAKA}

Amir, M. T., (2010), Inovasi Pendidikan melalui Problem Based Learning, Kencana, Jakarta.

Arends, R. I., (2008), Learning to Teach (Belajar untuk Mengajar), Pustaka Pelajar, Yogyakarta.

Astika, I. K. U., Suma, I. K., dan Suastra, I. W., (2013), Pengaruh Model Pembelajaran Berbasis Masalah terhadap Sikap Ilmiah dan Keterampilan Berpikir Kritis, e-Journal Program Pascasarjana Universitas Pendidikan Ganesha, 3.

Barbara, J. D., Susan, E. G., Deborah, E. A., (2001). Energizing Teacher Education And Professional Development with Problem Based Learning. Virginia: Stylus Publishing, LLC.

$\begin{array}{lr}\text { Pulungan, F. R., (2012), Pengaruh } \\ \text { Model } & \text { Pembelajaran } \\ \text { Problem } & \text { Based Learning } \\ \text { Berbasis } & \text { Pendidikan } \\ \text { Karakter } & \text { terhadap } \\ \text { Perubahan } & \text { Karakter dan } \\ \text { Kemampuan } & \\ \text { Menyelesaikan } & \text { Masalah }\end{array}$ 
Fisika, Jurnal Penelitian

Inovasi Pembelajaran

Fisika, 4: 38-43.

Rusman, (2012), Model-model

Pembelajaran:

Mengembangkan

Profesionalisme

Guru,

Rajawali Pers, Jakarta.

Sanjaya, W., (2011), Strategi Pembelajaran Berorientasi Standar Proses

Pendidikan, Kencana, Jakarta.

Saputri, F. L., Mahardika, I. K., dan Supriadi, B., Pembelajaran Berbasis Masalah Berorientasi Keterampilan Proses dalam Pembelajaran Fisika di SMP, Jurnal Pembelajaran Fisika.

Setiawan, G. C., Suprihati, T., dan Astutik, S., (2012), Penerapan Model Pembelajaran Problem Based Learning (PBL) disertai Media Komputer Makromedia Flash, Jurnal Pembelajaran Fisika, 1: 291-293.

Suhanda, Asmendri, dan Khaira, K., (2014), Penerapan Model Pembelajaran Berbasis Masalah dan Tutor Teman Sebaya terhadap Hasil Belajar Fisika Kelas VII MTSN Kota Solok, Jurnal Pendidikan MIPA, 1: 7476.

Tan, O. S., (2004). Enhancing
Thinking through Problem

Based Learning

Approaces. Singapore:

Thomson Learning. 